\title{
Queering New Cinema History: Affective Methodologies for Comparative Histories
}

\begin{abstract}
New Cinema History has tended to focus on developing microhistories of the exhibition, distribution, and reception of theatrical Hollywood and other mainstream cinemas. While such scholarship has been essential for understanding how cinema operates as a sociocultural institution, its focus on the highly public forms of cinemagoing that often followed Hollywood film has left untouched the sometimes furtive and deliberately hidden cinemagoing practices and microhistories of queer audiences, curators, and exhibitors throughout the mid-to-late 20th century. This paper intervenes in this state of affairs and queers New Cinema History. I situate film festival studies and New Cinema History within the same methodological and theoretical terrain and argue that the exclusion of queer film festivals from New Cinema History is a result of both the field's methodological preference for big data, as well as a structural heteronormativity underlying its methodologies. I further argue that by following affect, ephemera, and anecdotes, New Cinema History can better account for queer and other marginalised cinema practices.
\end{abstract}

\section{Keywords}

queer film festivals; affect; archive; sexuality; anecdotal theory

This paper is an intervention. New Cinema History, as this special issue notes, has tended to focus on micro-histories of cinema exhibition, reception, and distribution, and often with a focus on theatrical Hollywood and other mainstream and national cinemas. While such scholarship has been essential for understanding how cinema operates as a sociocultural institution, its focus on the highly public forms of cinema-going that often followed Hollywood film has left untouched the sometimes furtive and deliberately hidden cinema-going practices and micro-histories of queer audiences, curators, and exhibitors throughout the mid-to-late $20^{\text {th }}$ century. ${ }^{1}$

Two recent edited collections on New Cinema History fail to mention queer cinema in any form, and recent work on queer film festivals and on queer cinema distribution and production - which could 
conceivably be thought of as part of New Cinema History - does not situate itself in relation to the field. ${ }^{2}$ Even this edited collection's call for more comparative histories is evidence of this lacuna, as comparative histories and comparative approaches are perhaps the most common ways of studying queer film festivals. ${ }^{3}$ New Cinema History has been inattentive to this literature and has generally been inattentive to cinema institutions organized by marginalized communities. ${ }^{4}$ New Cinema History's focus on data-driven methodologies and its emphasis on the historical circulation of mainstream, feature-length cinema structurally excludes queer cinema institutions, which were until recently excluded from archives, mostly ignored in the press, and have otherwise left little physical trace of their existence. Tracing the histories of queer cinema institutions often requires an affective approach that attends to fleeting glances, possibilities, and subtexts, which is often incompatible with New Cinema History's underlying post-positivist paradigm and its focus on empirical data.

This paper intervenes in this state of affairs and queers New Cinema History. Following from the work of Antoine Damiens, who queers festival studies in order 'to reveal the political project and axiological coordinates' of the field, I queer New Cinema History in order to attend to the ways knowledge about cinema institutions is produced and reproduced. ${ }^{5}$ Like Damiens, I draw from a long history of queer media studies and queering media studies - from the strategies of reading against the grain made popular by feminist and queer critics throughout the 1970s, 1980s, and 1990s, to contemporary attempts to historicize queer media representation ${ }^{6}$ - to not just read queer histories into New Cinema History, but to undo New Cinema History's foundational assumptions about the ways it gathers data and analyzes information about cinema. What I aim to do with this article is show how New Cinema History's dominant methodological and theoretical frameworks structurally exclude queer cinema practices from its understanding of cinema as a sociocultural phenomenon, and develop new methodological strategies toward a more inclusive New Cinema History.

I make three moves in order to make my argument. First, in order to properly situate queer film festivals as an object of study that should be studied within New Cinema History, I identify the shared methodological and disciplinary ground between New Cinema History and film festival studies, and provisionally suggest that both fields can be considered part of a growing institutional turn in cinema and media studies. I do this in order to establish the citational and methodological foundations through which queer cinema can be brought into New Cinema History. Second, I explore the sorts of assumptions made by New Cinema History that makes it heteronormative field inattentive to queer cinema institutions. I show that the field's focus on data-driven approaches to research exclude 
ephemeral and experimental context of many queer cinema institutions. Film festival studies fares better at accounting for queer cinema practices because its grounding assumption of the ephemerality of film festival events does not preclude the use of ephemera as data. In the third and final move, I develop a comparative New Cinema History of three queer film festivals that takes affect seriously as a type of ephemeral data that can be used to write more adequate histories of queer cinema within New Cinema History.

\section{The first move: New Cinema History $\&$ film festival studies traverse the same methodological territory}

New Cinema History emerged in the mid-2000s and built on the empiricism of audience studies and the new film history to privilege thinking about cinema as a social institution. ${ }^{7}$ New Cinema History 'proposes that cinema is better understood as a social, rather than primarily textual, experience.'8 Methodologically, New Cinema Historians turn away from the film text as their primary source, and instead look at the broad field of historical sources that structure and regulate cinema as an institution, like fire maps, ledgers, correspondence, meeting minutes, oral testimony, and newspapers, but also aggregate forms of big cinema data like showtimes, venue sizes, audience attendance, and kinds of films screened. ${ }^{9}$ As Bronwyn Coate, Deb Verhoeven, and Alwyn Davidson note, New Cinema History '[focuses] on the overlapping networks of business, institutional, legislative and cultural practices that all contribute to bringing films and audiences to cinemas. ${ }^{10}$ This expanded notion of cinema history considers 'cinema as a social phenomenon' instead of as a text to be read. ${ }^{11}$

Film festival studies traverses similar territory. Film festival studies emerged in the mid-2000s independently from New Cinema History, but likewise also focused on the social and cultural features of cinema and has attempted to make sense of the unique role film festivals play in the exhibition, production, and distribution of film globally. Studies have turned to audiences, activism and politics, political economy, and have used a multiplicity of methodologies, including surveys, ethnography, and journalistic and academic case studies, to map out the complex and ever shifting relationships between cinema and festival networks. ${ }^{12}$ However, not all of the work that we might categorize under the loose rubric of "film festival studies" identifies as such; the notion of a distinct field that focuses on the study of film festivals is contested, as the numerous articles published in disciplines like leisure studies and event management that do not engage with the cinema studies 
literature attests. ${ }^{13}$ Despite this, Dina Iordanova argues that film festivals constitute a unique framework that transcends cinema studies' traditional foci on textual analysis, national cinemas, and industrial approaches. Film festivals, Iordanova argues, are situated within all three foci, but also somehow exceed any of their methodological tools, which requires that they are studied with separate theoretical and methodological framework, thus establishing the conditions through which we can conceptualize film festival studies as a field. ${ }^{14}$

Iordanova's framework stages an intervention into cinema studies and insists upon the value of film festivals as an object of study. However, this insistence, which Antoine Damiens notes is a common occurrence across the film festival literature, separates film festival studies as distinct from New Cinema History despite their shared methodological interest in cinema as a social phenomenon. ${ }^{15}$ What keeps these two literatures from overlapping more is the fact that film festival studies tends to focus on cinema within the present and from the perspective of being present, while New Cinema History often (but not always) focuses on the past. ${ }^{16}$ Marijke de Valck notes that what often makes festivals so appealing to festival researchers is 'their complete embrace of the present moment. Festivals take place in the here and now. ${ }^{17}$ There are, of course, exceptions to this presentism. de Valck's Film Festivals traces the early history of film festivals in Europe after World War II to the present, and Damiens's LGTBQ Film Festivals focuses on ephemeral queer film festivals in the 1970s and 1980s. ${ }^{18}$ Most studies of festivals have some historical component, but rather than being centred as the key contribution of the study, it is relegated to the status of context: useful for understanding the present, but not meaningful in its own right.

This temporal difference obscures the fact that at their cores, both New Cinema History and film festival studies are focused on the same objects: cinema as a sociocultural institution. These two fields should be in closer conversation with each other than they are, and should cite each other more often. There have been moments where this citational potential was nearly realized: at the 2017 History of Movie-going, Exhibition, and Reception (HoMER) conference in Toronto, where much of the research on New Cinema History is presented, a number of presentations were made on film festivals that fit in well with New Cinema History's overarching concerns. Indeed, Skadi Loist's ongoing project "Film Circulation on the International Film Festival Network and the Impact on Global Film Culture,” which uses data-driven methods to test the influence of film festivals on global cinema culture, is perhaps exemplary of the shared methodological territory of 
the two fields. ${ }^{19}$ Provisionally, then, I want to suggest that we should think of New Cinema History and film festival studies as occupying a growing body of research in cinema and media studies that we could name the institutional turn. The institutional turn focuses on, as New Cinema History does, cinema as a sociocultural institution, while making room for studies of cinemas in the present, as film festival studies does. The institutional turn also makes space for thinking about how cinema interacts with and is regulated by other institutions-which we could think broadly to include the state, but also other cinema and media institutions like collectives and co-ops, non-profits, distribution and production companies, video game producers, and other media companies and conglomerates.

Of course, work is already being done on these institutions, and much of this work is already in conversation with each other. ${ }^{20}$ By provisionally collecting all of this under the umbrella of the institutional turn, I am simply trying to establish the citational and methodological conditions through which queer cinema histories can be brought into New Cinema History. Film festival studies need not simply be concerned with festivals happening in the here and now; as my dissertation research showed, there are numerous historical queer film festivals with archival records that have been unconsidered by both festival scholars and New Cinema Historians. ${ }^{21}$ Moreover, queer cinema exists in a myriad of historical cinema institutions that could be important objects of study for New Cinema History. Queer film festivals are simply the most visible formation, making them particularly well-suited for consideration within New Cinema History.

\section{The second move: New Cinema History has been inattentive to the cinema practices of marginalized communities}

A focus on cinema institutions should also remain attentive to how bodies interact with each other and with cinema-a key concern for cinema studies since at least the feminist spectatorship theory of the 1970s. By focusing on how cinema as an institution is embedded within the social, the institutional turn marks an opportunity to think in concrete, material, and historically situated ways about how bodies relate within the sociocultural sphere of cinema. Without remembering that there are real human beings, real material bodies that watch and organize cinema, we may forget the lessons learned from feminist spectatorship theory: namely, that marginalized bodies have different engagements with cinema than the dominant white heteropatriarchal perspective. 
This lesson was foundational to Richard Maltby’s initial intervention into cinema history: he asserted that cinema history's task should be to write social histories "from below; that is, to write histories that are concerned not with the kings and queens of Hollywood but with their audiences and with the roles that these performances of celebrity played in the ordinary imaginations of those audiences." 22 Cinema history should not be simply a history of aesthetics, of auteurs, of stars and celebrities, but should focus on the very material conditions through which cinema became meaningful to ordinary people. For Maltby, this meant that cinema studies needed a new research agenda:

To begin with, we will need detailed historical maps of cinema exhibition, telling us what cinemas were where and when, amplified by whatever detailed evidence we can recover about the nature and frequency of attendance [...]. This data then needs to be combined with broader statistical information derived from census data and other surveys to amplify our understanding of cinema's audiences. ${ }^{23}$

This turn toward empirical audiences found in geographic and demographic data would, Maltby argued, produce a genuine social history of cinema from below. However, Judith Thissen notes that in the decade following the publication of Maltby's intervention, this social history is largely unrealized, and 'the New Cinema History has not yet produced a genuine turn toward social history or the corresponding paradigm shift. ${ }^{24}$ Instead, it has simply replaced the film text with audience demographics and movie theatres as privileged loci of analysis.

New Cinema History's foundational and ongoing focus on cinema's demographics and geography can never produce a true history from below. This is because demographic and geographic data are woefully inadequate at accounting for the histories of queer audiences and cinema institutions. For much of cinema's history, queer people simply have not been counted within census data and queer cinema has not been mapped. While in Canada researchers have been able to reliably use the census to identify same-sex couples since 2001, this demographic data excludes single queer people, and so its representativeness and adequacy is suspect. ${ }^{25}$ Likewise in Europe, census data also only allows the identification of couples, though the United Kingdom has asked questions about sexual identity in their Integrated Household Survey since $2011 .{ }^{26}$ Though this data may be useful for future data-driven studies of queer cinema audiences, our ability to only identify same-sex couples excludes single queers and other non-normative, non-monogamous family formations, and privileges homonormative forms of queer life. ${ }^{27}$ 
Even if this demographic data was adequately representative - not to mention epistemologically stable, since what we conceptualize as queer identity has shifted significantly over the last three centuries $^{28}$ - it would only be with great difficulty that we could then map it onto physical cinemas existing within cities, towns, and villages. Unlike gay bars and community centres, of which there are and have been many, there are few brick-and-mortar queer cinemas that we can point to in directories and on maps, with the noted exception of cinemas that may have existed within historically gay neighbourhoods. But reducing all queer cinemagoing to what happens within a commercial cinema in a gay neighbourhood is again, suspect, because of the increasing dispersion of queer spaces beyond gay neighbourhoods and beyond commercial spaces. ${ }^{29}$ Indeed, the very foundations of queer film festival culture were a response to the inability of commercial theatres to show films of interest to queer audiences, and so gay and lesbian activists organized 'parallel circuits' of queer film festivals to counteract a homophobic cinema exhibition and distribution culture. ${ }^{30}$ These festivals were not always organized at commercial cinemas; the first edition of San Francisco's Frameline festival was held in a community centre with the films projected on a bedsheet. ${ }^{31}$ This does not mean that queer people did not exist within cinema's industrial context-there is a wide body of scholarship (and gossip) about queer people in the industry. ${ }^{32}$ Sex, sexuality, and cinema go hand in hand; from the Hays Code to classification schemes and battles over censorship in the 1980s, sexuality has been a central feature of cinema's sociocultural and industrial context. But yet, New Cinema History has been inattentive to this fact, and instead tends to favour class and gender over sexuality as sociocultural identity lenses through which to understand cinema. ${ }^{33}$

If New Cinema History were truly and presently a history from below queer cinema practices would be a central feature of the scholarship. However, the methodological foundations of the field, its insistence on empirical data from commercial cinemas and censuses as primary sources, not to mention its temporal bias toward cinema history before 1960, renders absent the queer cinema histories that emerged in the latter half of the twentieth century, histories that often exist only as ephemera. ${ }^{34}$ Of course, when a paper trail - or data trail - does not exist, New Cinema Historians and queer historians have both turned to oral history to fill the gap. Annette Kuhn's work on cinema memories is exemplary in this regard. ${ }^{35}$ However, queer oral history is fraught given complexities over epistemologies of the closet, the historicization of queer identity, and the material fact that an entire generation of gay men was wiped out due to inaction over HIV/AIDS in the 1980s and 1990s. In the case of historical queer film festivals that no longer operate, organizers have often exited the network 
and pursued careers and lives elsewhere and are difficult, if not downright impossible, to find. In some cases you may not simply have enough evidence to tell an adequate micro-history.

For queer film festival scholars, the ephemerality of our archive is seen less as a barrier than it is a feature of our research design. As José Muñoz notes, evidence of queer life is often just ephemera:

Instead of being clearly available as visible evidence, queerness has instead existed as innuendo, gossip, fleeting moments, and performances that are meant to be interacted with by those within its epistemological sphere - while evaporating at the touch of those who would eliminate queer possibility. ${ }^{36}$

Rather than work against this ephemerality, we work with it, and bring together various ephemera from across different times and different places in order to make sense of queer film festivals. Ephemera is often difficult to integrate into current conceptual frameworks about data, which depend on thinking about data in aggregate and empirical terms. ${ }^{37}$ While studies of mainstream cinema practices can collect large amounts of various kinds of data -audience numbers, box office receipts, venue locations, and so on - this type of data is often unavailable for historical queer film festivals. We must critically assess New Cinema History's constant quest for more and more data. We must ask what kinds of histories data-driven cinema history may exclude, and crucially, we must also ask what counts as data within New Cinema History.

\section{The third move: a comparative New Cinema History that takes affect as data can better account for queer cinema practices}

I want to argue, in this third and final move, that attending to the place and role of affect can provide rigorous and compelling accounts of marginalized cinemas when conventional cinema data either does not exist or is in short supply. Following affect and comparing a particular affective formation at various festivals across time and space can offer a relational mode of comparison. A relational comparison aims to think through two or more sites not in terms of similarities and differences, but in terms of entanglements. These entanglements may not always be material: it may not be a particular body, object, or sign that entangles cinema institutions together. Rather, it may be affect - that is, the impulse to act and be acted upon - that entangles cinema institutions. ${ }^{38}$

Within cinema studies, the role of affect is often confined to studies that take textual analysis as their methodology. This is in part because of affect theory's reputation as a present-focused 
framework - affect happens in the here and now - and because of the long-standing interest cinema studies has on how spectators and empirical audience members react or respond to a film. ${ }^{39}$ Given New Cinema History's emphasis on the distribution and circulation of cinema, I want to argue here that the most useful approach to tracing affect through cinema institutions is Sara Ahmed's work on affective economies. Ahmed's conceptualization of an affective economy is

a theory of emotion as economy, as involving relationships of difference and displacement without positive value. That is, emotions work as a form of capital: affect does not reside positively in the sign or commodity, but is produced as an effect of its circulation. ${ }^{40}$

In an affective economy, signs, objects, and bodies do not have feelings, emotions, or affects; that is to say, they are not the source of affect. Rather, affect is produced through the circulation of signs, bodies, and objects, and 'the more signs circulate, the more affective they become. ${ }^{41}$ Films do not have affects that they transmit to audiences. Nor do newspapers, speeches, programs, programmers, audiences, journalists, and any of the countless signs, bodies, and objects that exist within film festival networks. Affect is not transmitted; affect circulates. Affect circulates as these signs, bodies, and objects moves through the film festival network. It sticks to the surface and rubs off when it comes into contact with another. This affect takes on a life of its own, and begins to draw other objects, other signs, and other bodies beyond the immediate sphere of the festival into its orbit, slipping and sliding, accumulating and discarding.

To demonstrate the usefulness of following affect in telling queer cinema histories, I briefly trace the affective economies of three queer film festivals held in three different Canadian cities at three different times: the inaugural 1987 edition of Counterparts International Festival of Gay and Lesbian Film, held in Winnipeg, Manitoba; the inaugural 1995 edition of The Fire I've Become: Queer Canadian Film \& Video Festival, held in Calgary, Alberta; and the third biennial 2000 edition of Queer City Cinema, held in Regina, Saskatchewan. While separated by years and thousands of kilometres, these three festivals are drawn together because they each played host to panic over what Michael Warner and Lauren Berlant have succinctly termed 'sex in public' brought about by the often unwitting and unintentional actions of queer film festival organizers. ${ }^{42}$ Each festival's panic ignited a flurry of affect that circulated within the festival network, entangling these dispersed festivals together. By following affect, I want to not only show the importance of considering affect as part of cinema's sociocultural context, but to also how affect can bring queer cinema institutions into New Cinema History. 
I follow affect by theorizing three anecdotes. I theorize anecdotes, as opposed to telling a grand narrative of queer film festival affect, as a way to further undo the data-driven orthodoxy of New Cinema History. As Jane Gallop writes:

The usual presupposition of theory is that we need to reach a general understanding, which then predisposes us toward the norm, toward a case or model that is prevalent, mainstream. To dismiss something as 'merely anecdotal' is to dismiss it as a relatively rare and marginalized case. ${ }^{43}$

For Gallop, anecdotal theory 'provides the opportunity to knot theory to the here and now,' to tie together the abstract and universal to the concrete and particular. ${ }^{44}$ Anecdotal theory provides an opportunity to knot queer cinema to New Cinema History. Queer life often exists as anecdotes, as marginalized cases resistant toward the norm. Following from Gallop, I theorize these three anecdotes to make New Cinema History 'more aware of its moment, more responsible to its erotics, and at the same time, if paradoxically, both more literary and more real. ${ }^{35}$

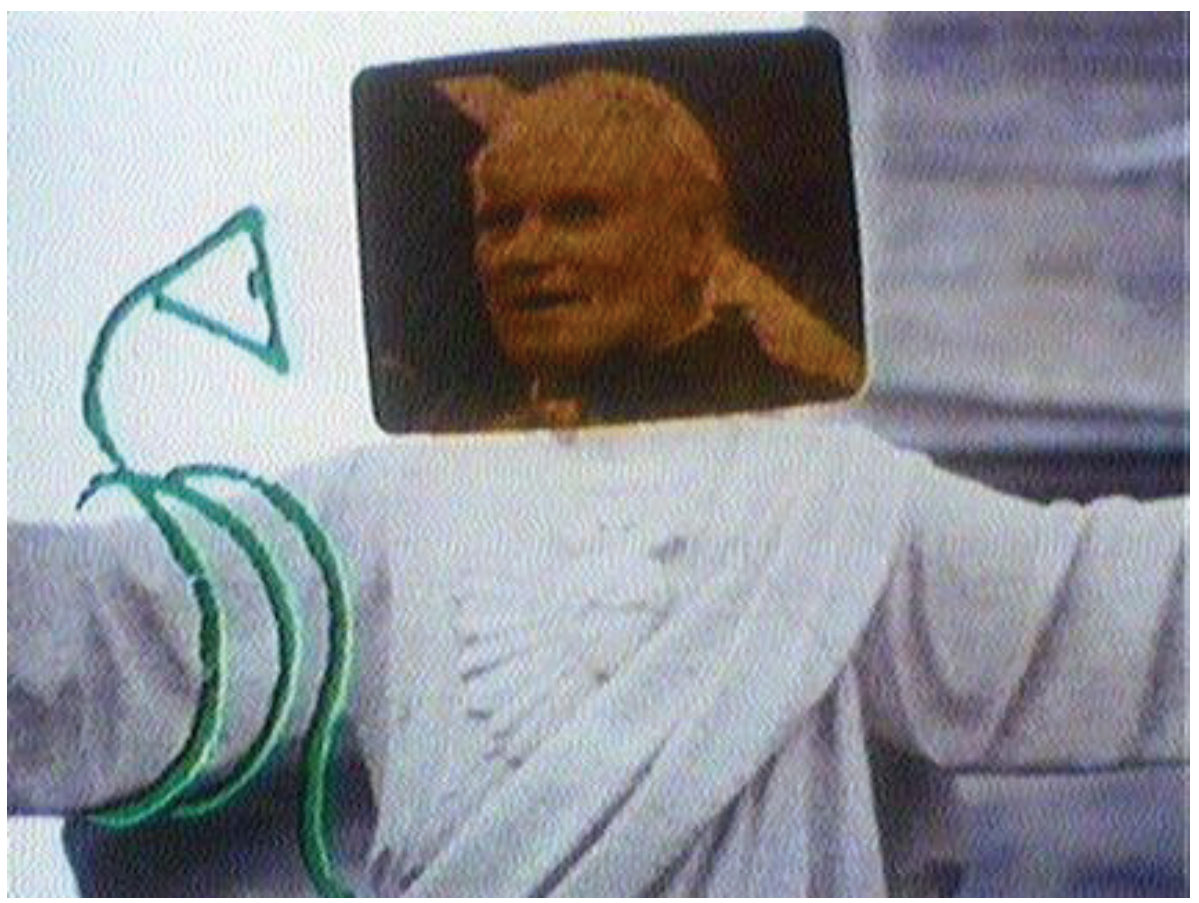

Figure 1. Still from Passiflora (Fernand Bélanger and Dagmar Teufel, Canada, 1985). 
Winnipeg, 21 April 1987. The Counterparts International Festival of Gay and Lesbian Film is weeks away. The Winnipeg Free Press publishes a preview of the festival, buried deep within the back pages of the paper. ${ }^{46}$ By all accounts, the preview probably should have gone unnoticed. But, with the headline 'AIDS Issues Take Front Row at First Gay Film Festival,' a description of the film Passiflora (Fernand Bélanger and Dagmar Teufel, Canada, 1985) as a 'homosexual body worship of the Pope and Michael Jackson,' rounded out with the fact that the provincial government was supporting the festival to the tune of $\$ 5,000$, it did not go unnoticed for long. ${ }^{47}$

Following this report, a flurry of correspondence and written material begins to circulate in Winnipeg protesting the festival. There are at least 41 discrete documents produced between the end of April and mid-May when the festival ends. Eight of these documents are letters protesting the New Democratic government's decision to direct funding to the festival and demand that they withdraw their funding. One of the festival's most vocal opponents is the Archbishop of Winnipeg, Adam Exner. ${ }^{48}$ The Archbishop writes a number of letters to organizers and the Ministry in which he excoriates the government and the festival for its 'bad taste':

The use of taxpayers money for the festival in question adds insult to injury and is intolerable. Taxpayers should not have to put up with use of their money in ways which are offensive, injurious and insulting to them. Furthermore, why should taxpayers finance a festival designed to promote and strengthen homosexual community which in a large measure is instrumental in the spread of the Aids [sic] epidemic, a serious health threat to all and an added cost to taxpayers? ${ }^{49}$

The rest of the letters against the festival are remarkably consistent in the ways they replay the same kind of discursive and affective moves that the Archbishop's letter makes. Morally wrong, warped, threatened, disgusted, sick, outrageous, pornographic - these words and words like them appear over and over again in the press, in the legislature, and continue to circulate within and around the festival. But does all of this outrage work? Does the government withdraw its support? The festival goes on that year without a hitch, but a year later, the government declines to renew its sponsorship. Officially, it's for financial reasons. ${ }^{50}$ Unofficially, it may have been because of the flurry of bad affect in 1987. 


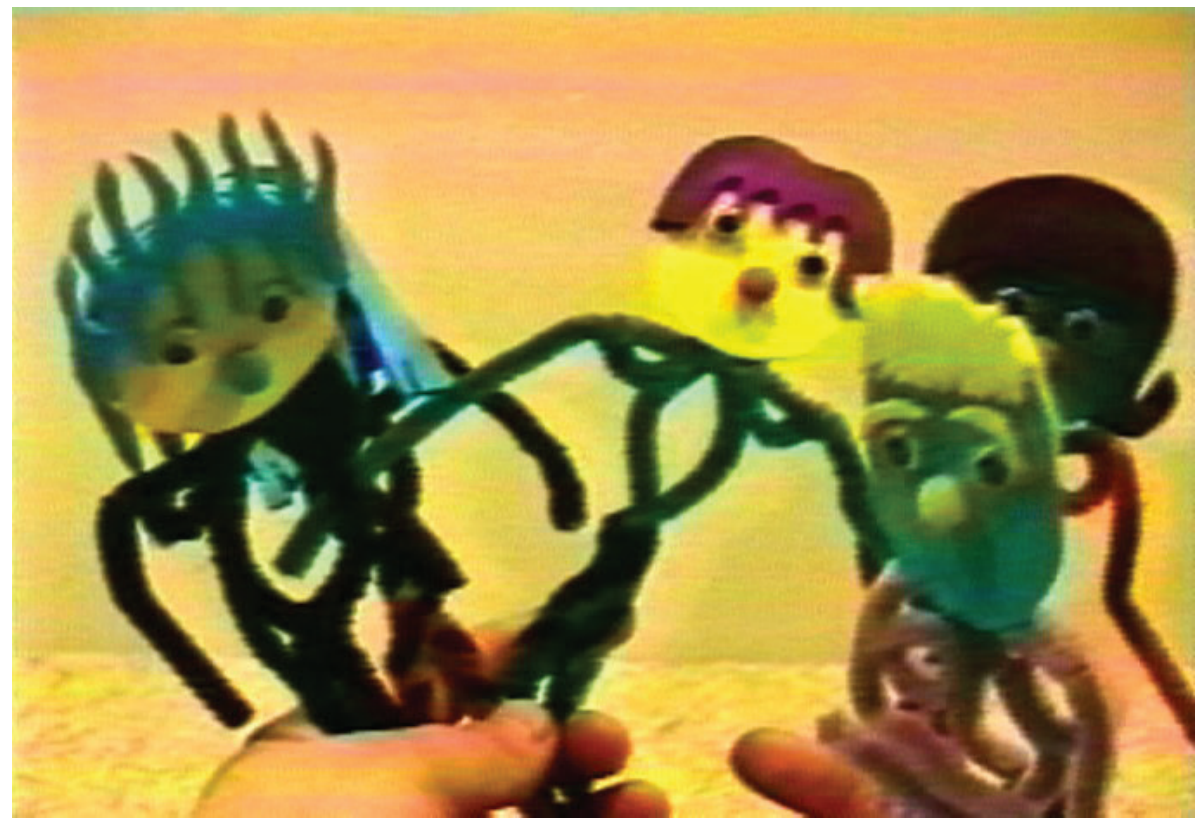

Figure 2. Still from Lessons in Baby Dyke Theory (Thirza Cuthand, Canada, 1995).

Calgary, 8 June 1995. The program for The Fire I've Become, a radical queer of colour film festival, is read on the air of conservative shock-jock Dave Rutherford's talk radio show. ${ }^{51}$ Taken out of context, Rutherford blusters that films like Wayne Fucking Peter Fucking Wayne (Wayne Yung, Canada, 1994), and Frank's Cock (Mike Hoolboom, Canada, 1993) have no business being supported by publicly-funded bodies like the Glenbow Museum, which was hosting the festival that year. He insinuates that 16-year-old Thirza Cuthand's film Lessons in Baby Dyke Theory (Canada, 1995) 'was about babies rather than about newly-out lesbians. ${ }^{52}$ Cuthand would recall later, 'One sleepy morning my mom showed me the paper and there was my name, along with a whole lot of garbage about how it was a recruiting film targeting children. ${ }^{53}$ The film was, of course, nothing of the sort, but Rutherford encourages listeners to call the Glenbow to express their disgust. As a result, the Glenbow is inundated with over 150 disgruntled phone calls and threatens to bar the organizers from holding the festival at their venue. ${ }^{54}$ Organizers hold a public meeting with Glenbow officials to educate them on the history of queer censorship and to convince officials to allow the festival to continue. ${ }^{55}$ Despite all of the panic, sensationalism, phone calls, and threats to call in the police, each night of the festival is a full house, only two protestors show up at a meagre rally against The Fire I’ve Become on opening night. ${ }^{56}$ 


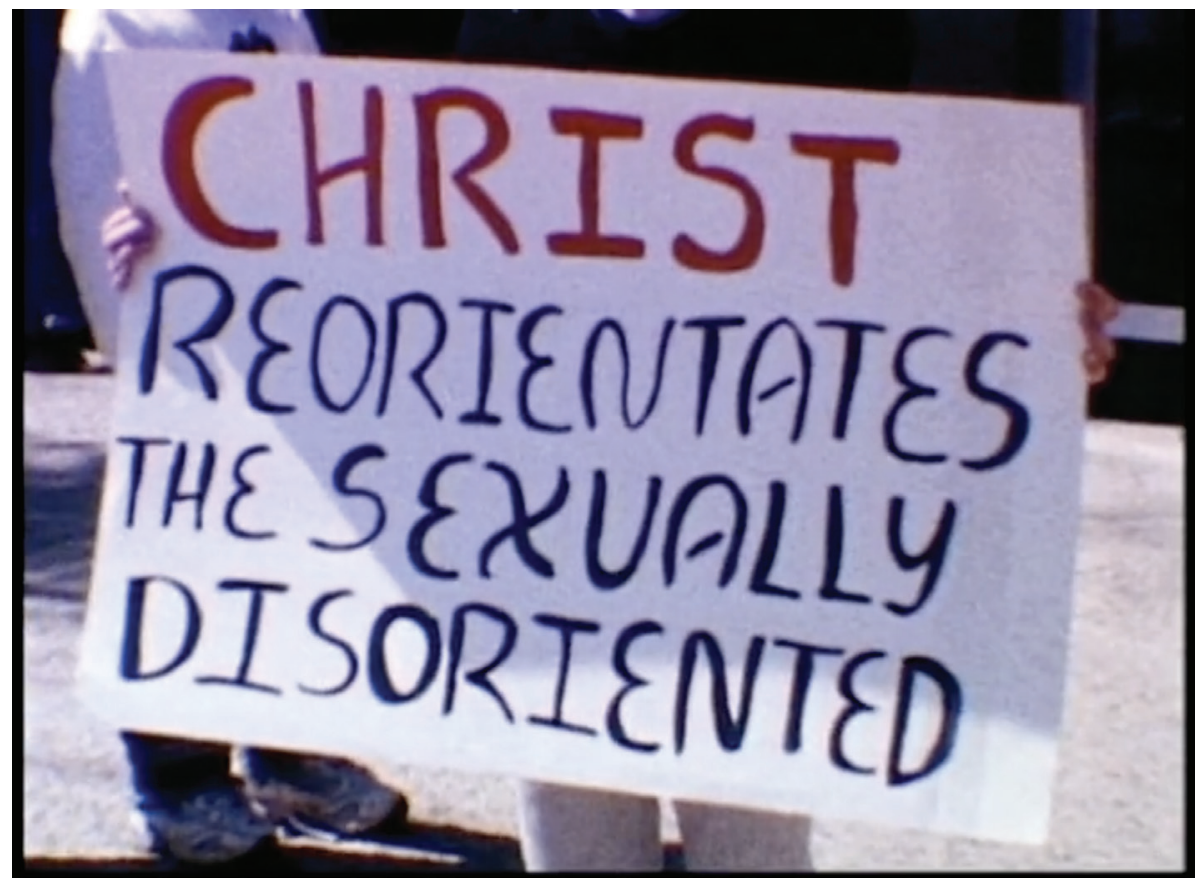

Figure 3. Still from Christian Porn (Roy Mitchell, Canada, 1990).

Regina, 28 April 2000. Saskatchewan Party opposition MLA June Draude rises to speak during question period. She asks why the New Democratic government is supporting Queer City Cinema, which is hosting a panel discussion on the intersections between community and pornography. More outrage, more bluster. The government gives non-answers. The opposition doesn't let up. Moments later, her colleague Arlene Jule asks the following question:

You must be very proud, Mr. Deputy Premier. Mr. Deputy Premier, this is absolutely sickening. Pornography is one of the most degrading, dehumanizing activities that human beings lower themselves to, and here we have your government using taxpayers' money to promote it. Mr. Deputy Premier, will you immediately, immediately cancel all Saskatchewan government sponsorship of this event ${ }^{57}$

13 May 2000, the day of the panel. A group of far-right Christian fundamentalists march outside of the downtown branch of the Regina Public Library. The group of white men and women are brandishing signs with slogans like 'Mothers and Fathers Your Public Library Hosts Gay Porn,' 'Christ Reorientates [sic] the Sexually Disoriented,' 'Gay Activists Expect Taxpayers to Fund Their 
Porn Addiction,' 'Shame on the Regina Public Library for Hosting Gay Porn,' and 'SaskTel Cuts Services, Raises Phone Rates and Donates to Queer City Porn Festival.' These protestors, documented in Roy Mitchell's short documentary Christian Porn (Canada, 2000), are called the Christian Truth Activists, led by notorious anti-gay and anti-choice activist Bill Whatcott. Festival organizer Gary Varro had assumed that the panel title might draw some attention to the festival, but did not think there would be a full-blown panic over it. But, as Mitchell sardonically voiceovers in his film: 'Oh but really, what do they think that a panel discussion on gay and lesbian porn on a Saturday afternoon in the public library is going to do to this little town?'

Within these stories a pattern emerges: the public gets wind of the government (or some public body) supporting the festival, whether through a newspaper report, a radio program, or through their elected representatives. A flurry of documentation and communication is produced: letters, phone calls, placards. Hands are wrung. Pearls are clutched. Won't someone please think of the children! And then, the festival ends. The fervour subsides, and then months or sometimes years pass before the festival is spoken of or written about again. Sometimes, this flurry of bad affect seriously jeopardizes the festival. The Fire I've Become only lasted one more year before succumbing to volunteer burnout. Counterparts struggled to find a consistent funding source after 1987 and went on a five-year hiatus in 1994. But sometimes, the bad affect launches the festival to new heights. Queer City Cinema was able to use the backlash to convince the Canada Council for the Arts to significantly increase their funding, allowing Queer City Cinema to mount a touring festival the following year. Affect is unpredictable and resists vast generalizations about its effects within a festival network.

As much as a film festival is an institution, it is also an event: an ephemeral occurrence within a specific time and place. ${ }^{58}$ But while the festival ends, affect continues to circulate. As Anne Cvetkovich argues, affect is often all that remains of queer life and is all that can be archived. ${ }^{59}$ The disgust, panic, and outrage felt over these festivals does not vanish; it continues to circulate. Affect becomes part of the sociocultural context through which we understand these festivals. Letters written by hand in a violent cursive on scraps of paper, conservative bluster over the airwaves and in the legislature, signs and protestors marching in circles - all of these moments are common to the histories of queer film festivals, not to mention queer culture writ large in the west. By expressing such negativity toward the festival, opponents were attempting produce knowledge about the festival that made it synonymous with disgust, with panic, with outrage. They are outraged and want you to be outraged. They are disgusted, so you should be disgusted. You should be disgusted because you are 
part of public, a body which the opponents imagine as a location occupied by themselves alone and separated from homosexuality. Homosexuality is not part of the public because it is disgusting. It is disgusting because it is not part of the public. And because it is not part of the public, it should not be receiving funds generated by the public.

These types of affective economies and emotional knowledges also resonate in the production of academic knowledge about queer film festivals. By following disgust, panic, and the sorts of negative affects that were common within the networks of queer film festivals in North America and Europe in the 1980s and 1990s, I am also trying to provide the sociocultural context for the exclusion of queer film festivals from New Cinema History. Numerous efforts were made by homophobic conservative activists to expel these festivals from the public, to keep them out of focus and out of the frame of what counts as part of acceptable movie-going activities during these decades. Cinema studies is not exempt from this long history of homophobia, and despite our field's extremely robust body of literature on queer cinema, there are still significant pockets within our discipline where queer cinema histories remain furtive and unacknowledged. By not acknowledging queer cinema institutions, New Cinema History is unwittingly still following the affective script laid out for them by these conservative activists: that queer film festivals are not part of the public, and therefore are not part of the history of movie-going, exhibition, or reception.

To be clear: I am not saying that New Cinema History is disgusted, outraged, or panicked by queer film festivals. Rather, its silence and inability to engage with cinema institutions created by queer and other marginalized communities makes the field complicit in the structural heteronormativity that denies queer people access to the public. This is only exacerbated by New Cinema History's quest for bigger data. We do not always have big data available for small, local queer film festivals; sometimes, all we have are anecdotes. But that should not mean we should exclude them from our studies. The micro-history and the anecdote must remain an important feature of studies of cinema institutions, or else we are at risk of losing not only queer cinema histories, but feminist, racialized, disabled, Indigenous, and so many other cinema histories of marginalized communities. Our histories do not always exist as data.

Comparative micro-histories are not unique within studies of queer film festivals. We compare because we have to, because that is the only way to make sense of the ephemera that documents our histories. The contribution I have tried to make here, then, is not to advocate for comparison as a methodology within New Cinema History; comparison is something that the field already does 
extremely well so long as it conceptualizes the literature on queer film festivals as within its parameters. Rather, I have advocated for New Cinema History to open its methods, its paradigms, its theories, and perspectives to other ways of studying cinema as a sociocultural institution. By following affect, New Cinema History can begin to grapple with its heteronormativity, think intersectionally, and rectify its ongoing and structural exclusion of the cinema histories of marginalized communities.

\section{Notes}

1 I use "queer" deliberately as an umbrella term for non-heterosexual sexual identities and communities, both their non-normative and normative forms. While such use may be perceived as ahistorical - since queer only became intelligible as an umbrella term in the early 1990s - and apolitical - since queer is used by academics and activists explicitly to highlight radical and non-normative sexualities - my use of queer is a strategic attempt to avoid terminological messiness and make as clear as possible the stakes of this paper. We need to reckon with the fact that queer life in any form over the last century has been excluded from New Cinema History.

2 Daniël Biltereyst, Richard Maltby, and Philippe Meers, eds., The Routledge Companion to New Cinema History (London; New York: Routledge, 2019); Richard Maltby, Daniël Biltereyst, and Philippe Meers, eds., Explorations in New Cinema History: Approaches and Case Studies (Malden, MA: Wiley-Blackwell, 2011).

3 For example see Jon Binnie and Christian Klesse, “Comparative Queer Methodologies and Queer Film Festival Research," Studies in European Cinema 15, no. 1 (January 2, 2018): 55-71, https://doi.org/10.1080/1 7411548.2018.1434364 and Stuart James Richards, The Queer Film Festival: Popcorn and Politics (New York: Palgrave Macmillan, 2017).

4 A noted exception to this is Arthur Knight's chapter on Black moviegoing in the American south; however, it still focuses on the exhibition of Hollywood cinema, and not experimental, avant-garde, or otherwise independent cinemas. See Arthur Knight, "Searching for the Apollo: Black Moviegoing and Its Contexts in the Small-Town US South," in Explorations in New Cinema History (Malden, MA: Wiley-Blackwell, 2011), $226-42$.

5 Antoine Damiens, LGBTQ Film Festivals: Queering Festival Studies, Curating Queerness (Amsterdam: Amsterdam University Press, 2020), 24. 
6 For work on reading against the grain see Richard Dyer, Now You See It: Studies on Lesbian and Gay Film (London; New York: Routledge, 1990), and Tania Modleski, The Women Who Knew Too Much: Hitchcock and Feminist Theory (New York: Methuen, 1988). For recent work that historicizes queer media representation see Roxanne Samer, “Revising 'Re-Vision': Documenting 1970s Feminisms and the Queer Potentiality of Digital Feminist Archives," Ada: A Journal of Gender, New Media, and Technology, no. 5 (July 7, 2014), doi:10.7264/N3FF3QMC, and Amy Villarejo, Ethereal Queer: Television, Historicity, Desire (Durham: Duke University Press, 2014).

7 Oft-cited examples of audience studies within New Film History include Tom Gunning, "An Aesthetic of Astonishment: Early Film and the (In)Credulous Spectator," in Film Theory \& Criticism, ed. Leo Braudy and Marshall Cohen, 7th ed. (New York; Oxford: Oxford University Press, 2009); and Miriam Hansen, Babel and Babylon: Spectatorship in American Silent Film (Cambridge: Harvard University Press, 1991). Bronwyn Coate, Deb Verhoeven, and Alwyn Davidson, "The Cinema Cities Index: Comparing Urban Cinema Cultures around the World,” Media International Australia 163, no. 1 (May 1, 2017): 164.

9 See Jeffery Klenotic, "Putting Cinema History on the Map: Using GIS to Explore the Spatiality of Cinema," in Explorations in New Cinema History, 58-84; and Deb Verhoeven, "Show Me the History! Big Data Goes to the Movies," in The Arclight Guide to Media History and the Digital Humanities, ed. Charles R. Acland and Eric Hoyt (Sussex: Reframe Books, 2016), 165-83.

10 Coate et. al., “Cinema Cities Index,” 164.

11 Daniel Biltereyst, Richard Maltby, and Philippe Meers, "Introduction: The Scope of New Cinema History," in The Routledge Companion to New Cinema History, ed. Daniel Biltereyst, Richard Maltby, and Philippe Meers (London; New York: Routledge, 2019), 2.

12 For an example of an audience-focused approach to film festivals see Liz Czach, "Cinephilia, Stars, and Film Festivals," Cinema Journal 49, no. 2 (Winter 2010): 139-45 For activism, see Dina Iordanova and Leshu Torchin, eds., Film Festival Yearbook 4: Film Festivals and Activism (St Andrews: St Andrews Film Studies, 2012). For political economy, see Ragan Rhyne, “The Global Economy of Gay and Lesbian Film Festivals,” GLQ: A Journal of Lesbian and Gay Studies 12, no. 4 (September 14, 2006): 617-19. For surveys, see Frederik Dhaenens, “Pink Programming across Europe: Exploring Identity Politics at European LGBT Film Festivals," Studies in European Cinema 15, no. 1 (January 2, 2018): 72-84. For ethnography and journalistic case studies see Daniel Dayan, “Looking for Sundance: The Social Construction of a Film Festival," in The Film Festivals Reader, ed. Dina Iordanova (St Andrews: St Andrews Film Studies, 2013), 45-58; Toby Lee, 
“Being There, Taking Place: Ethnography at the Film Festival,” in Film Festivals: History, Theory, Method, Practice, 122-37; and Richard Porton, ed., Dekalog 3: On Film Festivals (London: Wallflower, 2009).

13 For example, see Donald Getz, Tommy Andersson, and J. Carlsen, "Festival Management Studies: Developing a Framework and Priorities for Comparative and Cross-Cultural Research,” International Journal of Event and Festival Management 1, no. 1 (2010): 29-59; and Gyehee Lee, Tae-II Pae, and Lawrence J. Bendle, “The Role of Identity Salience in the Leisure Behavior of Film Festival Participants," Journal of Leisure Research 48, no. 2 (April 1, 2016): 156-77, https://doi.org/10.18666/ jlr-2016-v48-i2-4687.

14 Dina Iordanova, "The Film Festival and Film Culture's Transnational Essence," in Film Festivals: History, Theory, Method, Practice, ed. Marijke de Valck, Brendan Kredell, and Skadi Loist (London; New York: Routledge, 2016), xi-xvii.

15 Damiens, LGBTQ Film Festivals, 232.

16 Lydia Papadimitriou and Jeffrey Ruoff, "Film Festivals: Origins and Trajectories," New Review of Film and Television Studies 14, no. 1 (2016): 1, https://doi.org/10.1080/17400309.2015.1106686.

17 Marijke de Valck, "Introduction: What Is a Film Festival? How to Study Film Festivals and Why You Should," in Film Festivals: History, Theory, Method, Practice, ed. Marijke de Valck, Brendan Kredell, and Skadi Loist (London; New York: Routledge, 2016), 9.

18 Marijke de Valck, Film Festivals: From European Geopolitics to Global Cinephilia (Amsterdam: Amsterdam University Press, 2007).

19 "Film Circulation - Film Circulation on the International Film Festival Network," accessed December 5, 2019, http://www.filmcirculation.net/.

See Claudia Sicondolfo, “Filleing’ the Cinema Gap: The Precarity of Toronto’s Necessary Emerging Network of Feminist Film Critics," in Youth Mediations and Affective Relations, ed. Susan Driver and Natalie Coulter (Cham, Switzerland: Palgrave Macmillan, 2018), 117-95; Jennifer R. Whitson, Bart Simon, and Felan Parker, “The Missing Producer: Rethinking Indie Cultural Production in Terms of Entrepreneurship, Relational Labour, and Sustainability,” European Journal of Cultural Studies, December 21, 2018, https://doi.org/10.1177/1367549418810082; and Michael Zyrd, “A Report on Canadian Experimental Film Institutions, 1980-2000," in North of Everything: English-Canadian Cinema since 1980, ed. Wiliam Beard and Jerry White (Edmonton: University of Alberta Press, 2002), 392-401. 
21 Jonathan Petrychyn, "Networks of Feeling: Affective Economies of Queer \& Feminist Film Festivals on the Canadian Prairies” (PhD Diss., York University, 2019), https://yorkspace.library.yorku.ca/xmlui/ handle/10315/36773.

22 Richard Maltby, “On the Prospect of Writing Cinema History from Below," Journal for Media History 9, no. 2 (2006): 85 .

23 Maltby, "On the Prospect," 91.

24 Judith Thissen, "Cinema History as Social History: Retrospect and Prospect," in The Routledge Companion to New Cinema History, ed. Daniel Biltereyst, Richard Maltby, and Philippe Meers (London ; New York: Routledge, 2019), 124.

25 Sean Waite and Nicole Denier, “A Research Note on Canada's LGBT Data Landscape: Where We Are and What the Future Holds," Canadian Review of Sociology/Revue Canadienne de Sociologie 56, no. 1 (2019): 93-117, https://doi.org/10.1111/cars.12232.

26 Karin Schönpflug, Christine M. Klapeer, Roswitha Hofmann, and Sandra Müllbacher, "If Queers Were Counted: An Inquiry into European Socioeconomic Data on LGB(TI)QS," Feminist Economics 24, no. 4 (2018): 1-30, https://doi.org/10.1080/13545701.2018.1508877.

27 Lisa Duggan, The Twilight of Equality? Neoliberalism, Cultural Politics, and the Attack on Democracy, Nachdr. (Boston: Beacon Press, 2014).

28 Michel Foucault, The History of Sexuality Volume 1: An Introduction, trans. Robert Hurley (New York: Vintage, 1990).

29 Kath Browne and Leela Bakshi, "We Are Here to Party? Lesbian, Gay, Bisexual and Trans Leisurescapes beyond Commercial Gay Scenes,” Leisure Studies 30, no. 2 (2011): 179-96, https://doi.org/10.1080/ 02614367.2010.506651.

30 Skadi Loist, "The Film Festival Circuit: Networks, Hierarchies, and Circulation," in Film Festivals: History, Theory, Method, Practice, ed. Marijke de Valck, Brendan Kredell, and Skadi Loist (London; New York: Routledge, 2016), 49-64.

31 Skadi Loist and Ger Zielinski, "On the Development of Queer Film Festivals and Their Media Activism," in Film Festival Yearbook 4: Film Festivals and Activism, ed. Dina Iordanova and Leshu Torchin (St. Andrews: St. Andrews Film Studies, 2012), 49-62.

32 Vito Russo, The Celluloid Closet: Homosexuality in the Movies (New York: Harper \& Row, 1981); Thomas Waugh, The Fruit Machine: Twenty Years of Writings on Queer Cinema (Duke University Press, 2000). 
Hansen, Babel and Babylon; Annette Kuhn, An Everyday Magic: Cinema and Cultural Memory (London; New York: I.B.Tauris, 2002).

34 Ger Zielinski, “On Studying Film Festival Ephemera,” in Film Festivals: History, Theory, Method, Practice, ed. Marijke de Valck, Brendan Kredell, and Skadi Loist (London; New York: Routledge, 2016), 138-58. While there was a veritable explosion of queer activity after the Second World War in North America and Europe, there was also queer activity prior to the war, and it stands to reason that these pre-war queer people and queer communities would have gone to the cinema.

35 Kuhn, An Everyday Magic.

36 José Esteban Muñoz, “Ephemera as Evidence: Introductory Notes to Queer Acts,” Women \& Performance: A Journal of Feminist Theory 8, no. 2 (1996): 6, https://doi.org/10.1080/07407709608571228.

37 Verhoeven, "Show Me The History!"

38 Brian Massumi, Parables for the Virtual: Movement, Affect, Sensation (Durham: Duke University Press, 2002).

39 The literature on affect and cinema studies from a textual perspective is vast. For two recent attempts to overview the stakes of affect within cinema and media studies, see Hunter Hargraves, "The Urgency and Affects of Media Studies," Cinema Journal 57, no. 2 (Winter 2018): 137-42; and Margreth Lünenborg and Tanja Maier, “The Turn to Affect and Emotion in Media Studies," Media and Communication 6, no. 3 (September 11, 2018): 1-4, https://doi.org/10.17645/mac.v6i3.1732.

40 Sara Ahmed, The Cultural Politics of Emotion, 2nd ed. (Edinburgh: Edinburgh University Press, 2014), 45, emphasis original.

41 Ahmed, The Cultural Politics.

42 Lauren Berlant and Michael Warner, “Sex in Public,” Critical Inquiry 24, no. 2 (Winter 1998): 547-66.

43 Jane Gallop, Anecdotal Theory (Durham and London: Duke University Press, 2002), 7.

44 Gallop, Anecdotal Theory, 5.

45 Ibid., 11.

46 Morley Walker, “AIDS issues take front row at first gay film festival," Winnipeg Free Press (April 21, 1987), 31.

47 Jonathan Petrychyn and Claudia Sicondolfo, "Archived Passions, Censored Bodies: Passiflora and the Regulation of Sexuality at the NFB," Senses of Cinema, no. 90 (March 2019), http://sensesofcinema. com/2019/feature-articles/archived-passions-censored-bodies-passiflora-and-the-regulation-ofsexuality-at-the-nfb/. 
While most of the letters in the Ministry's files have been redacted in compliance with the province's privacy laws, it is still possible to identify two of the letters as originating from the Archdiocese of Winnipeg, and possibly from the Archbishop Adam Exner himself. This is possible because in the Plug In fonds at the Provincial Archives of Manitoba there is a letter from the Archbishop to Counterparts organizer Wayne Baerwaldt that uses some of the same language as a redacted letter to the Minister. Compare Archbishop of Winnipeg to Wayne Baerwaldt, April 23, 1987, Provincial Archives of Manitoba, Plug In ICA fonds, L-5-5-6 file 2; and Letter to Judy Wasylycia-Leis and Howard Pawley, April 23, 1987, Provincial Archives of Manitoba, Minister of Culture, Heritage and Tourism office files, D-5-7-13.

49 Letter to Judy Wasylycia-Leis and Howard Pawley, April 23, 1987, Provincial Archives of Manitoba, Minister of Culture, Heritage and Tourism office files, D-5-7-13.

50 Judy Wasylycia-Leis to Wayne Baerwaldt, November 24, 1987, Provincial Archives of Manitoba, Minister of Culture, Heritage and Tourism office files, D-5-7-13.

51 Joe Woodward, “Sodomizing the Public.” Alberta Report 22, no. 30 (1995): 32.

52 Mark Washeim, “Queer Film and Video Festival Threatened with Censorship,” Google Groups, June 21, 1995, https://groups.google.com/forum/\#!topic/misc.activism.progressive/W6tii2Jtq8c.

53 Thirza Cuthand, “The Hays Code and It’s Continuing Influence on Queer Subtext in Media,” October 4, 2006, http://www.thirzacuthand.com/?p=1052.

54 Washeim, "Queer Film and Video Festival".

55 Sanhita Brahmachari Pahl, “The Fire I’ve Become Queer Film and Video Festival,” The Herland Chronicle, October 1999, Glenbow Archives, herland feminist film festival fonds, M9329-32.

56 Woodward, “Sodomizing the Public,” 32; kevin d"souza, “Burning Down the House," MIX 21, no. 4 (April 1996): $34-5$.

57 Legislative Assembly of Saskatchewan Hansard, First Session, Twenty-Fourth Legislature, 28 April 2000, pg. 918.

58 Janet Harbord, “Contingency, Time, and Event: An Archaeological Approach to the Film Festival," in Film Festivals: History, Theory, Method, Practice, ed. Marijke de Valck, Brendan Kredell, and Skadi Loist (London; New York: Routledge, 2016), 69-82.

59 Anne Cvetkovich, An Archive of Feelings: Trauma, Sexuality, and Lesbian Public Cultures (Durham: Duke University Press, 2003). 


\section{Biography}

Jonathan Petrychyn is a Postdoctoral Fellow in Gender, Sexuality, and Digitality in the Department of Recreation \& Leisure Studies at the University of Waterloo. He received his PhD in Communication \& Culture from York University and Ryerson University in 2019. His research has been published in Senses of Cinema, Imaginations: Journal of Cross-Cultural Image Studies, and the Canadian Journal of Film Studies.

TMG Journal for Media History

Volume 23 No $(1 / 2) / 2020$

DOI

http://dx.doi.org/10.18146/tmg.588

PUBLISHER

Netherlands Institute for Sound and Vision

\section{COPYRIGHT}

Each article is copyrighted @ by its author(s) and is published under license from the author(s). When a paper is accepted for publication, authors will be requested to agree with the Creative Commons Attribution 4.0 International License. 